
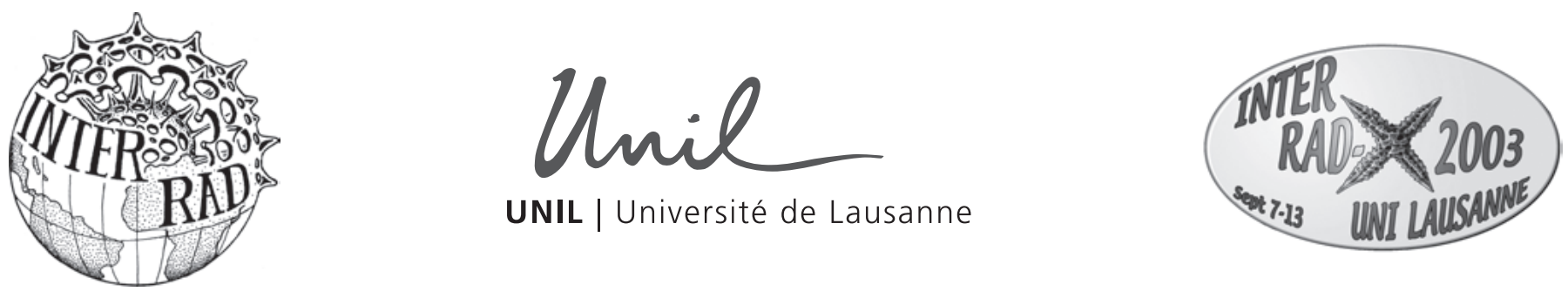

\title{
Radiolaria - Siliceous plankton through time
}

\author{
Proceedings of the Tenth Meeting of the International Association of Radiolarian Palaeontologists
}

INTERRAD X, held at the University of Lausanne, Switzerland, September 2003

\section{Preface}

\section{Peter O. Baumgartner}

Radiolaria are a very diverse marine siliceous microplankton group that have existed at least since the Cambrian to the Recent. Fossil Radiolaria were known since the middle of the 19th Century and studied by many scientists at the turn of the 19th/20th Century, in part as a consequence of the discoveries made in samples collected be the HMS Challenger expeditions. Intense biostratigraphic radiolarian research was spurted again in the early 1970's by the Deep Sea Drilling Project. Biochronologic zonations based on samples recovered by Ocean Drilling were first proposed for the Tertiary (Riedel \& Sanfilippo 1978) and the Cretaceous (Foreman 1973, 1975). However, the radiolarites, cherty oceanic sediments associated with ophiolites, had so far only been studied in thin sections. This changed when radiolarian workers discovered the use of hydrofluoric acid to extract Radiolaria from chert and other siliceous rocks (Dumitrica 1970, Pessagno \& Newport 1972) The new method allowed to work on land samples from mountain ranges that had undergone burial diagenesis or even metamorphosis. As a consequence, radiolarian biochronology was rapidly extended into the Jurassic, Triassic and the Palaeozoic (Pessagno 1977, Pessagno et al. 1979, Yao et al. 1980, Nakaseko \& Nishimura 1979, Holdsworth \& Jones 1980). A major obstacle to the elaboration of detailed biochronozones is the discontinuous nature of the radiolarian record, due to spotty preservation. Biogenous, opaline silica is unstable in the ocean and in the diagenetic environment. Large amounts of the more delicate radiolarian tests become dissolved already during their descent in the water column and in the bottom sediments (Takahashi \& Honjo 1981). During early diagenesis, opaline silica dissolves and radiolarians become preserved either as casts of the mould that leaves the dissolved test, or as replacement by quartz, pyrite or other minerals. In Palaeozoic and Mesozoic samples, usually only robust forms are preserved. However, exceptionally well preserved samples from special diagenetic environments, such as Middle Jurassic manganese carbonate nodules (Yao 1997), or euxinic environments like the Late Jurassic Solnhofen Limestone (Zügel 1997, Dumitrica \& Zügel 2002) show several hundred morphotypes, a diversity that rivals with the diversity of living radiolarians. These samples teach us, that the average radiolarian assemblage extracted by harsh chemical treatments from rocks is a poor residue of dissolution resistant forms. The consequence of this unavoidable fact is the discontinuous record of radiolarian ranges, which greatly hampers biochronologic correlation. A major

Institut de Géologie et Paléontologie, Université de Lausanne, Anthropole, CH-1015 Lausanne, Switzerland. E-mail: Peter.Baumgartner@unil.ch 
step in resolving this problem has been the use of the Unitary Associations method (Guex 1977, 1991). Already in early attempts for a Jurassic-Cretaceous radiolarian zonation (Baumgartner et al. 1980), we realised that this method allows integration of the data on mutual co-occurrence of all considered taxa from all studied sections, thus overcoming local gaps of preservation. Unitary Associations represent maximal sets of co-occurring taxa that are put in a stratigraphic sequence by their identification in all studied sections. Starting in 1984 (Baumgartner 1984a,b) computer programs (Guex and Davaud 1982) allowed the calculation of Unitary Associations from large data sets. The largest data set so far treated was the MRD database on Middle Jurassic to Early Cretaceous radiolarians (Baumgartner et al. 1995). A radiolarian biozonation including 22 Unitary Association Zones for the Middle Jurassic to Early Cretaceous interval was calculated with the Biograph software (Savary \& Guex 1991). Today the majority of Mesozoic radiolarian biozonations are based on Unitary Associations. An excellent example is presented in this volume (Beccaro, this volume). A new software, UA-Graph (Hammer et al. 2001) has been developed.

Dating pelagic sediments by radiolarian biochronology has totally changed our understanding of the geology of Tethyan and Circumpacific mountain ranges. Suture zones and ophiolites, interpreted in the frame of plate tectonics as remnants of ancient oceans, needed to be dated. A vast campaign of sampling and dating radiolarites started in the 1980's and is still going on.

Today, Radiolaria are an important microfossil group used worldwide to date mostly basinal sediments of the entire Phanerozoic.

The spectacular diversity of Radiolaria has spurted biogeographic and palaeo-oceanographic studies based on radiolarian assemblages from Cenozoic (Hollis, this volume, Moore 1978) to recent samples (Yamashita et al. 2002) from all oceans. In the modern ocean about 400 known species occupy almost all ecologic niches from shallow water to the deep ocean. Many species are endemic to certain water masses and can therefore be used as oceanographic tracers (Casey 1971a,b). The distribution of Late Tertiary to Holocene Radiolaria in piston cores from the world's oceans have been widely used to trace paleooceanographic features, such as the upwelling zones (Caulet et al. 1992), the growth and vane of polar water masses through the Ice Ages (Romine and Moore 1981, Vénec-Peyré et al. 1997) as well as the major current systems, such as the Humbolt Current (Molina-Cruz 1977).

This volume gives a representative view of research topics discussed at the 10th International Meeting of Radiolarian Palaeontologists, held at the University of Lausanne in 2003. A large effort is currently made to refine and better understand Palaeozoic and early Mesozoic radiolarian biochronology (Feng et al. this volume, Marquez et al. this volume, Wonganan \& Caridroit this volume). Cherts associated with basalts and other ophiolitic rocks are often the only remnants of Palaeozoic and Mesozoic ocean basins. Their reconstruction is essentially based on biochronologic ages and palaeobiogeographic affinities of Radiolaria. Much work has dealt with radiolarian faunal changes related to major geologic boundaries in the Palaeozoic (Wang \& Luo this volume), at the PermoTriassic boundary (DeWever et al. this volume), and in the Cenozoic (Hollis, this volume). Mesozoic radiolarian biochronology continues to be improved and better calibrated (Danelian this volume, Beccaro this volume, Bandini et al. this volume).

For a number of years, the radiolarian community is concerned with the development of databases. With the rapid development of computer technologies, databases have become more and more sophisticated and for the last few years only, have become available online. There has been a common agreement among radiolarian specialists, that Radiolaria.org is the portal that provides links to most radiolarian databases and hosts a wealth of information on Radiolaria and radiolarian workers (Dolven, this volume).

\section{REFERENCES}

Baumgartner, P. O. 1984a: Comparison of Unitary Associations and probabilistic ranking and scaling as applied to Mesozoic radiolarians. Computer \& Geosciences 10(1), 167-184.

Baumgartner, P. O. 1984b: A Middle Jurassic-Early Cretaceous low-latitude radiolarian zonation based on unitary associations and age of Tethyan radiolarites. Eclogae Geologicae Helvetiae 77(3), 729-837.

Baumgartner, P. O., Bartolini, A., Carter, E., Conti, M., Cortese, G., Danelain, T., Dumitrica-Jud, R., Gorican, S., Guex, J., Hull, D., Kito, N., Marcucci, M., Matsuoka, A., Murchey, B., O’Dogherty, L., Savary, J., Vishnevskaya, V., Widz, D. \& Yao, A. 1995: Middle Jurassic to Early Cretaceous Radiolarian Biochronology of Tethys Based on Unitary Associations. In: Baumgartner, P. O., O'Dogherty, L., Gorican, S., Urquhart, E., Pillevuit A., \& De Wever, P. (Eds): Middle Jurassic to Lower Cretaceous Radiolaria of Tethys: Occurrences, Systematics, Biochronology, Mémoires de Géologie (Lausanne), 23, 1013 1043.

Baumgartner, P. O., de Wever, P. \& Kocher, R. 1980: Correlation of Tethyan Late Jurassic Early Cretaceous radiolarian events. Cahiers de Micropal. C.R.N.S., 1980/2, 23-72

CASEY, R. E. 1971a: Distribution of polycystine Radiolaria in the oceans in relation to physical and chemical conditions. In: Funnell, B. M., \& Riedel, W. R. (Eds.): The Micropalaeontology of Oceans, Cambridge, UK: Cambridge University Press, 151-159.

CASEY, R. E. 1971b: Radiolarians as indicators of past and present water-masses In: Funnell, B. M., \& Riedel, W. R. (Eds.): The Micropalaeontology of Oceans, Cambridge, UK: Cambridge University Press, 331-341.

Caulet, J. P., Vènec-Peyré, M.-T., Vergnaud-Grazzini, C. \& Nigrini, C. 1992: Variation of South Somalian upwelling during the last $160 \mathrm{ka}$ : radiolarian and foraminifera records in core MD 85674. Geological Society Special Publication.

DumitricA, P. 1970: Cryptocephalic and cryptothoracic Nassellaria in some Mesozoic deposits of Romania. Revue roumaine de Géologie, Géophysique et Géographie (série Géologie) 14(1), 45-124.

Dumitrica, P. \& ZüGel, P. 2002: Mendacastrum n. gen. and Domuzdagia n. gen., two Jurassic spherical Spumellaria (Radiolaria) with hagiastrid medullary shell. Micropaleontology 48(1), 23-34.

Forman, H. P., 1973: Radiolaria of Leg 10 with systematics and ranges for the families Amphipyndacidae, Artostrobiidae, and Theoperidae. In: Worzel, J.L., Bryant, W., et al. (Eds): Initial Reports of the Deep Sea Drilling Project, 10, U.S. Government Printing Office, Washington DC, 407-474. 
Forman, H. P. 1975: Radiolaria from the North Pacific, Deep Sea Drilling Project, Leg 32. In: Larson, R. L., Moberly, R. et al. (Eds): Initial Reports of the Deep Sea Drilling Project, 32. U. S. Government Printing Office, Washington, D.C., 579-676.

Guex, J. 1977: Une nouvelle méthode d'analyse biochronologique. Bull. Géol. Lausanne, 224, 309-322. Bull. Géol. Lausanne, 313, 317-340.

GueX, J. 1991: Biochronologic Correlations. Springer-Verlag, 1-252.

GuEx, J. \& DAvaud, E. 1982: Recherche automatique des associations unitaires en biochronologie. Bull. Soc. Vaud. Sci. Nat., 76, no. 361, 53-69.

Holdsworth, B. K. \& Jones, D. L.1980: Preliminary radiolarian zonation for late Devonian through Permian time. Geology 8(6), 281-285.

Molina CRUZ, A. 1977: Radiolarian assemblages and their relationship to the oceanography of the subtropical southeastern Pacific. Marine Micropaleontology 2(4), 315-352.

Moore, T. C. 1978: The distribution of radiolarian assemblages in the modern and ice-age Pacific. Marine Micropaleontology 3(3), 229-266.

NAKASEKO, K. \& Nishimura, A. 1979: Upper Triassic Radiolaria from southwest Japan. Science Reports, College of General Education, Osaka University, 28, 2 (2), 61-109.

Pessagno, E. A., JR. 1977: Upper Jurassic Radiolaria and radiolarian biostratigraphy of the California Coast Ranges. Micropaleontology 23(1), 56113.

Pessagno, E. A., JR., Finch, W. \& Aвbott, P. L. 1979: Upper Triassic Radiolaria from the San Hipolito Formation, Baja California. Micropaleontology 25(2), 160-197.

Pessagno, E. A. \& Newport, R. L. 1972: A technique for extracting Radiolaria from radiolarian cherts. Micropaleontology 18(2), 231-234.

Riedel, W. R. \& SANFILIPPO, A. 1978: Stratigraphy and evolution of tropical Cenozoic radiolarians. Micropaleontology 24(1), 61-96.
Romine, K. \& Moore, T. C., JR. 1981: Radiolarian assemblage distributions and paleoceanography of the eastern equatorial Pacific Ocean during the last 127,000 years.; CLIMAP's regional ocean dynamics. Palaeogeography, Palaeoclimatology, Palaeoecology 35(2-4), 281-314.

SAVARY, J. \& GUEX, J. 1991: BioGraph: un nouveau programme de construction des corrélations biochronologiques basées sur les associations unitaires. Bull. Géol. Lausanne, 313, 317-340.

TAKAHASHI, K. \& HonJo, S. 1981: Vertical flux of Radiolaria; a taxon-quantitative sediment trap study from the western tropical Atlantic. Micropaleontology 27(2), 140-190.

Hammer, Ø., Harper, D.A.T. \& RyAn, P. D. 2001: PAST: Paleontological Statistics Software Package for Education and Data Analysis. Palaeontologia Electronica 4(1): 1-99, http://palaeoelectronica.org/2001_1/past/ issue1_01.htm

Venec Peyre Marie, T., Caulet, J. P. \& Vergnaud grazzini, C. 1997: Glacial/ interglacial changes in the equatorial part of the Somali Basin (NW Indian Ocean) during the last 355 kyr. Paleoceanography 12(5), 640648.

YAO, A. 1997: Faunal change of Early - middle Jurassic radiolarians. News of Osaka Micropaleontologists 10, 155-182.

Yao, A., Matsuda, T. \& Isozaki, Y. 1980: Triassic and Jurassic radiolarians from the Inuyama area, central Japan. Journal of Geosciences, Osaka City University 23, 135-154.

YAMAShitA, H., TAKAHASHI, K. \& FUJITANI, N. 2002: Zonal and vertical distribution of radiolarians in the western and central Equatorial Pacific in January 1999. Deep-Sea Research 11, 49, 2823-2862.

ZügEL, P. 1997: Discovery of a radiolarian fauna from the Tithonian of the Solnhofen area (Southern Franconian Alb, southern Germany). Paläontologische Zeitschrift 71, 197-209. 